\title{
Traumatic dental injuries in young children
}

\author{
Traumatismos dentais em crianças pequenas \\ Traumatismos dentales en niños pequeños \\ Karine TAKAHASHI ${ }^{1}$ \\ Isabela Copetti FARIA ${ }^{1}$ \\ Natália Oliveira NEVES ${ }^{1}$ \\ Sthepane Barbosa MONTANO ${ }^{1}$ \\ Heitor Ceolin ARAUJO ${ }^{2}$ \\ ${ }^{1}$ Universidade do Oeste Paulista (UNOESTE, Curso de Odontologia 19050-920, Presidente Prudente-SP, Brasil \\ ${ }^{2}$ Mestrando, Programa de Pós-Graduação em Ciência Odontológica, UNESP Univ Estadual Paulista, 16015-050 Araçatuba-SP, Brasil
}

\begin{abstract}
Introduction: Dental trauma is a frequent occurance in Dentistry. They often occur in early childhood, between 0 to 3 years old, when children begin to learn their first steps, to play and run, because their habilities are not refined. Objective: The purpose of this article is to verify the occurance of traumatic dental injury in primary teeth in a children population. Material and Method: seventy-eight child from 0 to 6 years old male and female were evaluated. The study was conducted in Regional Hospital of Presidente Prudente. Children were evaluated by a questionary about occurance of traumatic injury, cause and search for attendance. The data were collected and submited to Spearman correlation test. Results: Traumatic dental injury occurs in deciduous teeth in $(44,8 \%)$ of the population, more common in males $(68,5 \%)$, at two years old $(28,5 \%)$ and in front superior region $(91,5 \%)$ in the upper central incisors $(48,5 \%)$. Conclusion: By the use of correlation test of Spearman, it was possible to verify that there is a positive correlation between the factors: darkness and mobility, darkness and search for treatment, early loss and satisfactory treatment and search for treatment and satisfactory treatment.
\end{abstract}

Descriptors: Tooth Injuries; Dentition; Dental Care.

\section{Resumo}

Introdução: O traumatismo dentário é uma ocorrência frequente em odontologia. Muitas vezes ocorrem na primeira infância, entre 0 a 3 anos, quando as crianças começam a aprender seus primeiros passos, a brincar e correr, porque suas habilidades não são refinadas. Objetivo: O objetivo deste artigo é verificar a ocorrência de lesões dentárias traumáticas em dentes primários em uma população infantil. Material e Método: Foram selecionadas 78 crianças de 0 a 6 anos do sexo masculino e feminino do Hospital Regional de Presidente Prudente, 35 crianças foram avaliadas, pois haviam sofrido trauma, e seus pais preencheram um questionário sobre ocorrência de lesão traumática, causas e atendimento. Os dados foram coletados por meio de questionário e submetidos ao teste de correlação de Spearman $(\mathrm{P}<0,05)$. Resultados: ocorreu lesão dentária traumática em dentes decíduos em $(44,8 \%)$ da população, mais comum nos homens $(68,5 \%)$, aos dois anos de idade $(28,5 \%)$ e na região frontal superior $(91,5 \%)$ nos incisivos centrais superiores $(48,5 \%)$. Conclusão: Foi possível verificar que há uma correlação positiva entre os fatores: escurecimento e mobilidade, escurecimento e busca de tratamento, perda precoce e tratamento satisfatório e busca tratamento e tratamento satisfatório.

Descritores: Traumatismos Dentários; Dentição; Assistência Odontológica.

\section{Resumen}

Introducción: El traumatismo dental es una ocurrencia frecuente en odontología. Muchas veces ocurren en la primera infancia, entre 0 a 3 años, cuando los niños empiezan a aprender sus primeros pasos, a jugar y correr, porque sus habilidades no son refinadas. Objetivo: El objetivo de este artículo es verificar la ocurrencia de lesiones dentales traumáticas en dientes primarios en una población infantil. Material Y Métodos: Se seleccionaron 78 niños de 0 a 6 años del sexo masculino y femenino del Hospital Regional de Presidente Prudente, 35 niños fueron evaluados, pues habían sufrido trauma, y sus padres llenaron un cuestionario sobre ocurrencia de lesión traumática, causas y atención. Los datos fueron recolectados en un cuestionario y se sometió a la prueba de correlación de Spearman (P $<0,05)$. En la mayoría de los casos, se observó un aumento en la incidencia de la enfermedad de Chagas, \%) en los incisivos centrales superiores (48,5\%). Conclusión: Fue posible verificar que hay una correlación positiva entre los factores: oscurecimiento y movilidad, oscurecimiento y búsqueda de tratamiento, pérdida precoz y tratamiento satisfactorio y busca tratamiento y tratamiento satisfactorio

Descriptores: Traumatismos de los Dientes; Dentición; Atención Odontológica.

\section{INTRODUCTION}

Dental traumatisms are the main emergency events in dentistry ${ }^{1}$. Traumatic injuries are the result of impacts, where the attacking force overcomes the resistance found in bone, muscle and dental tissue and the extent of those injuries is directly related to the intensity, type and duration of the impact ${ }^{2}$. Its occurrence is more frequent in childhood, due to the observed relationship between growth factors and physical and mental development of children ${ }^{3}$. Trauma in the primary dentition may result in sequelae both on the traumatized teeth as on their successors. The deciduous teeth that have suffered trauma may have bleeding pulp, color changes, premature loss, internal or external resorption, pulp obliteration, ankylosis and pulp necrosis. The permanent successors the most common changes are hypocalcification and enamel hypoplasia, beyond the root laceration or coronary, odontoma formations, interruption or change of root formation and disturbances in eruption. Traumatic injuries in primary dentition generate discomfort situations, because it compromises the oral cavity and there is an emotional involvement of the child and family ${ }^{4,5}$.

Children with trauma in the primary dentition requires a different approach from that held in the permanent dentition, this is because there is a close relationship between the deciduous tooth apex affected by trauma and the germ of the successor permanent tooth $^{6,7}$.

The upper arch and the central incisive are the most affected, starting with enamel fracture, followed by the color change, which are the most common types of trauma. The most frequent cause is a fall from height ${ }^{8-16}$. 
It is important to conduct a good interview, a good clinical examination and laboratory tests to provide a quick and appropriate treatment plan and postoperative follow-up, and in the cases of dentoalveolar trauma, it is important to know how to classify injuries and the structures involved ${ }^{17}$.

In the literature there is a great variety of studies trying to establish a pattern of involvement, however, there is still controversy ${ }^{18-20}$. The lack of knowledge regarding the measures to prevent and treat cases of trauma and guide caregivers is also a problem $^{21-27}$.

Traumatisms in the primary dentition are common in children, since they are starting their activities as walking, running, cycling, and are a direct cause of loss of deciduous teeth. Therefore further studies to evaluate the prevalence and pattern, of involvement of primary teeth should be encouraged in an attempt to seek for more effective ways of preventing and improving the quality of life for children. For these reasons, it is the general practice dentist obligation, not only to the pediatric dentist, to provide emergency care to patients suffering from these injuries. First, knowing reassure the parents and guardians, as they are going through a time of great emotional discharge, but also by performing proper diagnosis and treatment.

The objective of this study is to verify the presence of dental trauma in children aged 0-6 years old at the Regional Hospital of Presidente Prudente. And also check the most frequent types of its causes and if there was specialized care.

\section{MATERIAL AND MÉTHOD}

This study was approved by the Research Ethics Committee of the University of West Sao Paulo, and all those responsible for the patients who participated in the survey were duly informed and signed the Free and Informed Consent Form.

Seventy-eight children who attended the Hospital were evaluated $45(57,5 \%)$ male and $33(42,5 \%)$ female, with ages ranging between 0 and 6 years. The exclusion criteria were: children whom parents or guardians refused to participate or refused to sign the consent form; children who did not fit the age group 0-6 years and have some systemic condition that prevents them from having their proper motor development."

They were evaluated through a validated qualitative questionnaire applied to parents or guardians, where they were questioned about the presence of trauma, the cause and whether there were treated in specialized care.

The data collected on record were reported in Microsoft Excel spreadsheet for further statistical analysis. For this we used the Statistica Statsoft ${ }^{\circledR}$ South America software, using the correlation nonparametric Spearman.
RESULTS

Seventy-eight mothers or guardians who frequented the Regional Hospital of Presidente Prudente of the pediatric wards and pediatric beds were interviewed. Of the total, $35(44.8 \%)$ reported trauma in primary teeth and $43(55.2 \%)$ reported no occurrence of trauma (Figure 1).

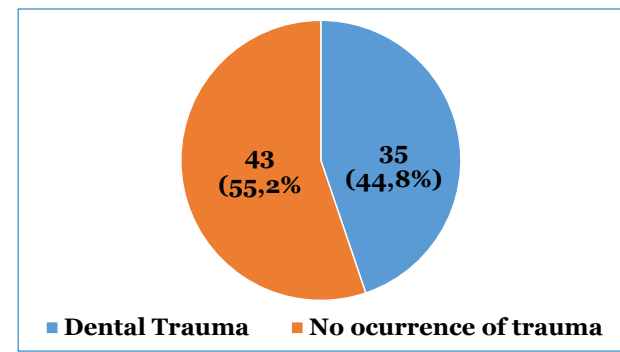

Figure 1: Prevalence of dental trauma.

According to the evaluation of the questionnaires, it can be seen that the most affected gender was male $24(68,5 \%)$ and female $11(31,5 \%)$ (Figure 2). Of the 35 affected, 100\% reported that the trauma was related to fall or hit, which is equivalent to a physical trauma. When it comes to age, most of the trauma occurred at 2 years $10(28.5 \%)$, followed by 4 years $9(25.5 \%)$ and 6 years $8(23 \%)$, and 3 years old with $5(15 \%)$ and 5 years old with $3(8 \%)$ (Figure 3).

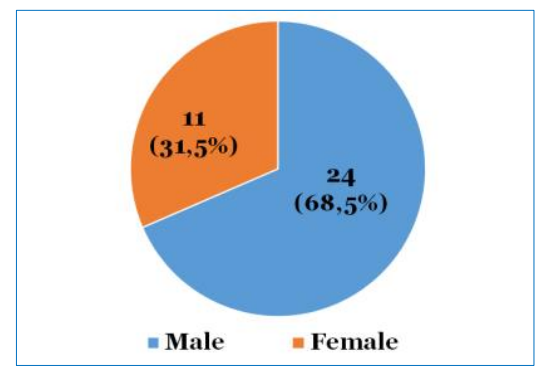

Figure 2: Prevalence of dental trauma by gender.

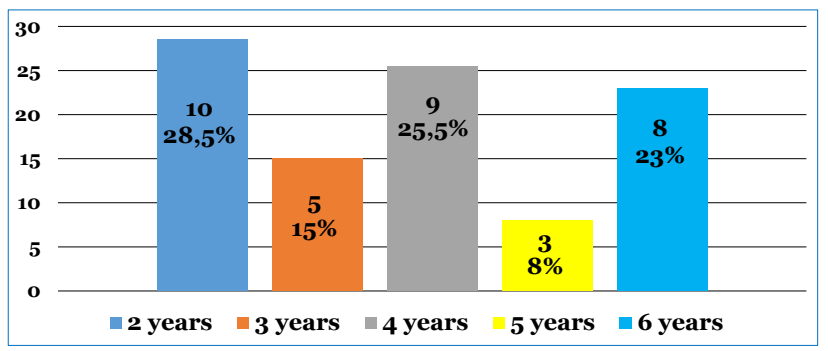

Figure 3: Age of dental trauma.

The region with most prevalence of trauma was the upper anterior $32(91,5 \%)$, followed by the lower anterior $2(5.5 \%)$, and the region with less trauma was the upper posterior region 1 (3\%) (Figure 4). The most affected teeth due to trauma was the upper right central incisive $17(48,5 \%)$, followed by the upper left central incisive $12(34,3 \%)$, while the left lower central incisive is $3(8.5 \%)$. The teeth that were less affected were the upper right lateral incisive and the upper right first molar and upper left canine 1 (2.9\%) (Figure 5). In 23 (65.5\%) there were 
no reports of color change in dental crown, only 12 $(34,5 \%)$ reported presence of browning (Figure 6). The treatment was sought in most cases 27 (77.2\%) only $8(22,8 \%)$ did not seek treatment for trauma (Figures 7 and 8).

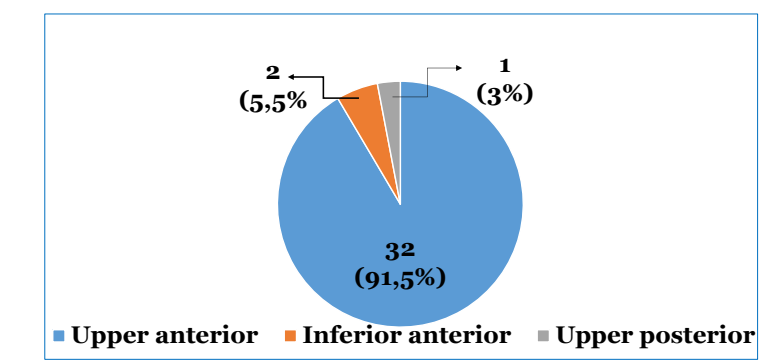

Figure 4: Prevalence of trauma by region.

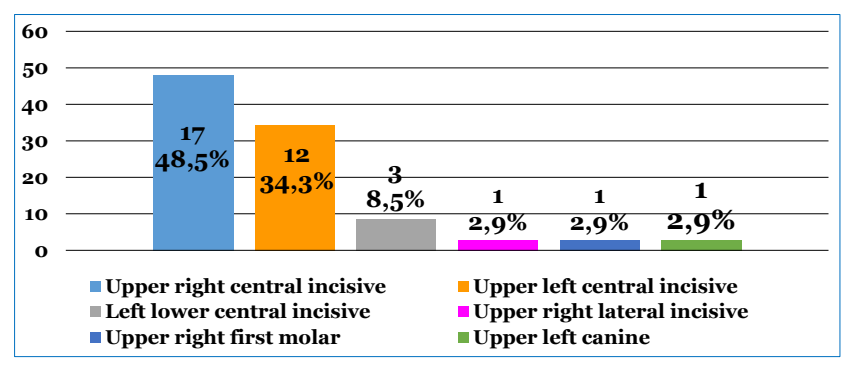

Figure 5: Affected by trauma.

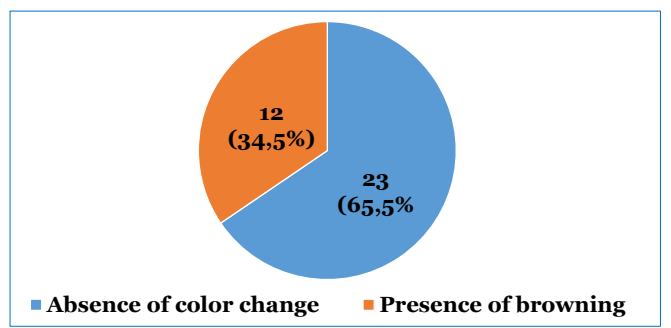

Figure 6: Color change in dental crown.

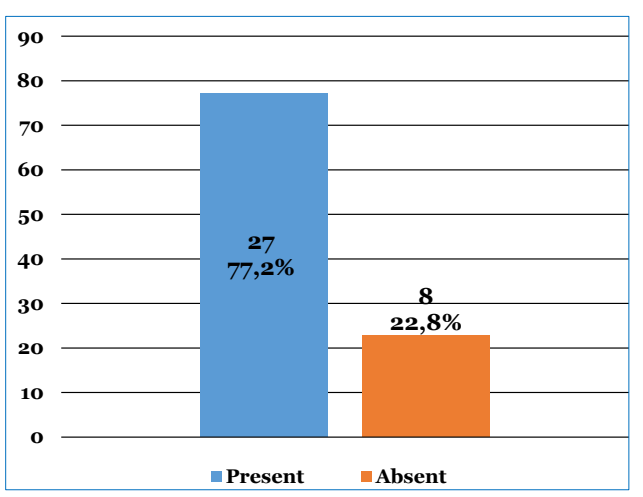

Figure 7: Treatment.



Figure 8: Treatment.
In cases that the mother or responsible were looking for treatment only $8(22,8 \%)$ were performed by a pediatric dentistry, and $27(77.2 \%)$ was conducted by a general practice dentistry (Figure 8 ).

After applying the Spearman correlation test, it was found positive correlation ship between the following variables ( $\mathrm{p}<0.005)$ : Darkening $X$ Mobility; Darkening $X$ Search for treatment; Mobility $X$ Browning; early loss X Satisfaction; Search for X treatment satisfaction; X Early Loss.

\section{DISCUSSION}

Dentoalveolar trauma is considered a public health problem due to its high occurrence, and to have physical and emotional consequences and high cost of treatment ${ }^{28}$.

Traumatic injuries mainly affect the anterior teeth, thus, great problems of pediatric dentistry, it reaches a large number of children ${ }^{28}$ as seen in our study.

When a professional is asked to meet a patient who suffered trauma, he needs to be ready to solve physical problems and also, emotional problems of the child and family. The professional should be prepared to calm the child and parents ${ }^{29}$.

The prevalence and incidence of these injuries have increased in several countries. The highest number of trauma in primary teeth occurs between the ages of 10 months to 3 years old. Boys are more affected and the most affected teeth are the maxillary central incisive $^{28}$. These facts were confirmed in our study. Children of the city of Florianópolis, in 2002, were found with a high prevalence of trauma in primary teeth, aged 1-3 years in boys, due to fall, with multiple dental trauma and dental luxation as more frequent injury ${ }^{25,29}$.

According to the study of Chowdary et al. ${ }^{28}$ the male are more affected (66\%), corroborating with our results $(68,5 \%)$.

In $44.6 \%$ of the teeth soft changes were observed in the color of the crown and in our work we also observed $65,5 \%{ }^{29}$. Granville-Garcia et al. ${ }^{30}$ also found high prevalence of trauma in primary dentition, with greater involvement of the male, and the tooth 61 . However, the enamel fracture was the type of injury that was most found. The same data confer with the results published by Kawabata et al. ${ }^{31}$ e Sousa et al. ${ }^{32}$.

When the occurrence of injuries is studies it is found a large involvement of patients with 1 year of age, and accidents at home are the most common cause. There is no gender difference. However, there is great variability of results according to the region studied $^{33}$.

Rajab et al. $^{33}$ found a higher prevalence of injuries involving boys, with the falls in schools being the most common cause. The same was 
verified by Kramer et al. ${ }^{34}$ in 2009, that found that 34 years old are the most prevalent ages.

Kramer et al. ${ }^{34}$ found a prevalence of $23.6 \%$ of traumatism, with no statistically significant difference between gender. The most affected age group was 2-3 years old. The authors claim that this age group is most affected; it is the time when the child begins to acquire autonomy. Already at 12 months old, children have certain limitation of movement and many teeth are not erupted yet.

Wendt et $\mathrm{al}^{35}$ observed the prevalence of trauma is $36,6 \%$, while Bhayya and Shyagalli ${ }^{38}$, noted that $76.13 \%$, in our study, we observed the prevalence of $44,8 \%$.

Losso et al. ${ }^{27}$ noted the importance of dealing with traumatic injuries in deciduous teeth, always thinking of the consequences to the permanent successor. The authors found prevalence in the age group of 1 to 3 years old.

Patients with protrusion of the superior central incisive are at a higher risk group ${ }^{36}$. However, a study with children in Saudi Arabia in 2001 found no relationship with accentuated overjet ${ }^{37}$.

As in our study, Chalissery et al. ${ }^{38}$, found that the upper central incisors are the most affected in cases of dental traumatism.

Regarding the etiological factors, falls resulting from sports and games always appear as the main factor. Second, are the objects and car accidents $^{28}$. Researches have shown that caregivers and teachers do not have adequate knowledge of how to handle patients that suffered trauma, which probably happens in developing countries ${ }^{39-41}$. On the other hand, developed countries show a better preparation of teachers in schools, and also better prepared environments to prevent their occurrence.

Low demand for specialized care after traumatic injuries in deciduous teeth is actually found in the literature. It can be attributed to the lack of knowledge of the consequences to the germ of the permanent tooth ${ }^{36}$.

Assunção et al. ${ }^{1}$ state that there is a great variability of results when studying age, gender, etiology and the most affected teeth regarding dental trauma in early childhood, which is mainly due to region studied.

We as dentists should be engaged in the role of preventing the occurrence of trauma. Prevention is predominant in pediatric dentistry, like fighting to prevent caries, periodontal disease, malocclusion and other oral diseases. We must also try to prevent the occurrence of dental injuries. Unfortunately, our ability to prevent such things is limited. Live and grow results in a high risk of trauma. Children only learn to walk after several falls. Preventive measures including excessive protrusion correction from anterior incisive, use of chairs and seat belts, use of mouth guard in sports and parental supervision in recreational activities for children are necessary measures to prevent this type of problem ${ }^{28}$.

\section{CONCLUSION}

Dental trauma occurred in the primary dentition in $44.8 \%$ of the studied population, and the most affected gender was male $(68.5 \%)$, at the age of 2 years old $(25.71 \%)$ in the anterior region $(91.4 \%)$ in the upper central incisive (51.42\%). By employing the Spearman correlation test, there was a positive correlation between the following factors: darkening and mobility, dimming and demand for treatment, early loss and satisfactory treatment, seeking treatment and satisfactory treatment.

\section{REFERENCES}

1. Assunção LRS, Cunha RF, Ferelle A. Análise dos traumatismos e suas seqüelas na dentição decídua: uma revisão de literatura. Pesqui bras odontopediatria clín integr. B. Odontopediatria. Clin. Integr. 2007;7(2):173-79.

2. Duarte DA, Bonecker MJS, Sant'anna GR, Suga SS. Caderno de odontopediatria: lesões traumáticas em dentes decíduos: tratamento e controle. Santos; 2001.

3. Moss SJ, Macaro H. Examination, evaluation and behavior management following injury to primary incisors. NY State Dent J. 1985;51(2):87-92.

4. Campos JADB, Zuanon ACC, Pansani CA. Traumatismo na dentição decídua e suas conseqüências na dentição permanente. ROBRAC 2001;10(30):26-8.

5. Alexandre GC, Campos V, Oliveira M. Luxação intrusiva de dentes decíduos. Rev Assoc Paul Cirur Dent. 2000;54(3):215-19.

6. Santos V, Seabra S, Chevitarese Z. Traumatismo dentário numa visão de promoção de saúde. Saúde \& Amb Rev. 2010;5(1):1-7.

7. Zembruski C. Estudo da prevalência de traumatismos na dentição decídua em préescolares do município de Canoas RS [dissertação]. Campinas: Universidade Camilo Castelo Branco; 2001.

8. Cunha RF, Pugliese DMC, Vieira AE. Oral trauma in Brazilian patients aged 0-3 years. Dent traumatol. 2001;17(5):210-12.

9. Della Valle D, Chevitarese ABA, Modesto A, Castro LA de. Frequência de traumatismo dentário em bebês. Rev Ibero-am Odontopediatr Odontol Bebê. 2003;6(34):464-69.

10. Meira R, Barcelos R, Primo LG. Respostas do complexo dentino-pulpar aos traumatismos em dentes decíduos. JBP $-\mathrm{J}$ Bras Odontopediatr Odontol Bebê. 2003;6(29):50-5.

11.Porto RB, Freitas JS, Cruz MR, Bressani AE, Barata JS, Araújo FB. Prevalence of dentoalveolar traumatisms in the urgency pediatric dental clinic of FO UFRGS. Rev Fac Odontol 
Porto Alegre. 2003;44(1):52-6.

12. Vasconcellos RJH, Oliveira DM, Nogueira RVB, Maciel AP, Cordeiro MC. Trauma na dentição decídua: enfoque atual. Rev cir traumatol bucomaxilo-fac. 2003;3(2):17-24.

13.Simões FG, Leonardi DP, Baratto Filho F, Ferreira EL, Fariniuk LF, Sayão SMA. Fatores etiológicos relacionados ao traumatismo alvéolodentário de pacientes atendidos no pronto socorro odontológico do Hospital Universitário Cajuru. RSBO. 2004;1(1):50-5.

14. Scarpari CEO, Possobon RF, Moraes ABA. Ocorrência de traumatismo em dentes decíduos de crianças atendidas no Cepae-FOP/UNICAMP. J Bras Odontopediatr Odontol Bebê. 2004; 7(35):33-40.

15.Zaze ASF, Assunção LRS, Provenzano MGA, Franzin LCS, Ferelle A, Cunha RF. Avaliação de traumatismos dentários em crianças assistidas em um pronto atendimento odontológico. Pesq Odontol Bras. 2004;18(sup):221.

16. Oliveira FAM, Oliveira MG, Orso VA, Oliveira VR. Traumatismo Dentoalveolar: revisão de Literatura, Rev cir traumatol buco-maxilo-fac. 2004;4(1):15-21.

17.Amorim NA, Silva TRC, Santos LM, Tenório MDH, Reis JIL. Urgência em Odontopediatria: perfil de atendimento da Clínica Integrada Infantil da FOUFAL. Pesq Bras Odontoped Clin Integr. 2007;7(3):223-27.

18. Moura LFAD, Ferreira DLA, Melo CP, Sady MCLM, Moura MS, Mendes RF et al. Prevalência de injúrias traumáticas em crianças assistidas na clínica odontológica infantil da Universidade Federal do Piauí, Brasil. Pesq. Bras. Odontopediatria Clin Integr. 2008;8(3):341-45.

19.Gulinelli JL, Saito CT, Garcia-Júnior IR, Panzarini SR, Poi WR, Sonoda CK et al. Occurrence of tooth injuries in patients treated in hospital environment in the region of Araçatuba, Brazil during a 6-year period, Dent Traumatol. 2008;24(6):640-44.

20.Tzigkounakis V, Merglová V. Attitude of Pilsen primary school teachers in dental traumas. Dent Traumatol. 2008;24(5):528-31.

21.Trombini CS, Feldens EG, Feldens CA. Luxação intrusiva em dentes decíduos: relato de caso, Stomatos, 2008;14(27):74-86.

22.Cabral ACR, Duarte DA, Climene Valentim. Prevalência das injúrias traumáticas na dentição decídua. Rev odontol Univ Cid São Paulo. 2009;21(2):137-43.

23. Oliveira MSB, Carneiro MC, Amorim TM, Maia VN, Alvarez AV, Vianna MIP et al. Contexto familiar, traumatismo dentário e oclusopatias em crianças em idade pré-escolar: ocorrência e fatores associados. Rev Odontol UNESP. 2010; $39(2): 81-8$.
24.Cardoso M, de Carvalho Rocha MJ. Traumatized primary teeth in children assisted at the Federal University of Santa Catarina, Brazil. Dent Traumatol. 2002;18(3):129-33.

25. Siqueira MB, Gomes MC, Oliveira AC, Martins CC, Granville-Garcia AF, Paiva SM. Predisposing factors for traumatic dental injury in primary teeth and seeking of post-trauma care. Braz Dent J. 2013;24(6):647-54.

26.Firmino RT, Siqueira MBLD, Vieira-Andrade RG, Gomes GB, Martins CC, Paiva SM et al. Prediction factors for failure to seek treatment following traumatic dental injuries to primary teeth. Braz oral res. 2014;28(1):1-7.

27.Losso EM, Tavares MCR, Bertoli FMP, Baratto Filho F. Tarumatismo dentoalveolar na dentição decídua. RSBO. 2011;8(1):e1-20.

28. Chowdary GN, Hemalatha R, Vijayakumar R, Ganhesh R, Selvakuma H, Mangauyarkarasi S. Prevalence of traumatic dental injuries in primary teth: A retrospective study. SRM J Res Dent Sci. 2014;5(1):11-3

29. Souza Filho MD, Moura MS, Araújo RSRM, Araújo MAM, Moura LFAD. Prevalência de traumatismo dentário em pré-escolares de Teresina, PI. Arq Odontol. 2011;47(1):18-24.

30.Granville-Garcia AF, Menezes VA, Lira PIC. Prevalência e fatores sócios-demográficos associados ao traumatismo dentário em préescolares. Odontol clín-cient. 2006;5(1):57-64.

31. Kawabata CM, Sant'Anna GR, Duarte DA, Mathias MF. Estudo de injúrias traumáticas em crianças na faixa etária de 1 a 3 anos no município de Barueri, São Paulo, Brasil. Pesqui Bras Odontopediatria Clin Integr. 2007;7(3):229-33.

32. Sousa DL, Moreira Neto JJS, Gondim JO, Bezerra Filho JG. Prevalência de trauma dental em crianças atendidas na Universidade Federal do Ceará / Prevalence of dental trauma in children attending the Federal University of Ceará. Rev Odonto Ciênc. 2008;23(4):355-59.

33. Rajab LD. Traumatic dental injuries in children presenting for treatment at the Department of Pediatric Dentistry, Faculty of Dentistry, Universit of Jordan. Dent Traumatol. 2003;19(1):6-11.

34.Kramer PF, Gomes CS, Ferreira SH, Feldens CA, Viana ES. Traumatismo na Dentição Decídua e Fatores Associados em Pré-Escolares do Município de Canela/RS, Pesq Bras Odontoped Clin Integr. 2009;9(1):95-100.

35. Wendt FP, Torriani DD, Assunção MC, Romano AR, Bonow ML, da Costa CT, Goettems ML et al. Traumatic dental injuries in primary dentition: epidemiological study among preschool children in South Brazil. Dent Traumatol.2010; 26(2):168-73. 
36. Bhayya DP, Shyagali TR. Traumatic injuries in the primary teeth of 4- to 6-year-old school children in gulbarga city, India: a prevalence study. Oral Health Dent Manag. 2013; 12(1):17-23.

37.Al-Majed I, Murray JJ, Maguire A. The Prevalence of dental trauma in 5-6 and 12-14 year-old boys in Riyadh, Saudi Arabia. Dent Traumatol. 2001;17(4):153-58.

38. Chalissery VP, Marwah N, Jafer M, Chalisserry EP, Bhatt T, Anil S. Prevalence of anterior dental trauma and its associated factors among children aged 3-5 years in Jaipur City, India - A cross sectional study. J Int Soc Prev Community Dent. 2016;6(1):35-40.

39.Hanan SA, Costa SK. Conhecimento dos professores de $1^{\text {a }}$ a $4^{\text {a }}$ série de escolas públicas municipais de Manaus/AM frente à avulsão dentária. Pesq Bras Odontoped Clin Integr 2010;10(1):27-33.

40.Glendor U. Epidemiology of traumatic dental injuries-12 year review of the literature. Dent Traumatol. 2008;24(6):603-11.

41. Khahabuka FK, Plasschaert A, van 't Hof M. Prevalence of teeth with untreated dental trauma among nursery and primary school pupils in Dae es Salaam, Tanzania. Dent Traumatol. 2001;17(3):109-13.

\section{CONFLITO DE INTERESSES}

Os autores declaram não haver conflitos de interesse.

AUTOR PARA CORRESPONDENCIA

Heitor Ceolin Araújo

heitorceolin@hotmail.com

Submetido em 21/09/2018

Aceito em 12/03/2019 